$$
\begin{aligned}
\mathrm{S} \text { E C Cンクリートのブリーデイング特性に関する一考察 } \\
\text { 山本 光彦* 櫻井 清一* } \\
\text { 伊藤 祐二* 笠井 哲郎** }
\end{aligned}
$$

\title{
A Study on Bleeding Characteristics of SEC Concrete
}

by

\author{
Teruhiko YAMAMOTO*, Seiichi SAKURAI*, \\ Yuji ITO* and Tetsuro KASAI**
}

SEC method is one type of two-stage-mixing method of concrete. It had been found that SEC concrete produced by this mixing method had reduced bleeding, improved segregation resistance and high flowability under vibration, and improved strength characteristics and durability. Also, the fact that SEC concrete exhibited excellent properties after hardening was related to the bleeding reduction effect of this concrete. Therefore, in order to improve the bleeding characteristics of this concrete, the authors examined the influence of differences in concrete mixing method, procedure of materials charging, and material temperature. As a result, it was found that the bleeding of cement paste, mortar and concrete produced by the SEC (Sand Enveloped with Cement) method were reduced to about $40 \%$ compared to the case of normal mixing of the same proportion. The authors proposed a model on the composition of cement particles in concrete, which can explain the reduction of bleeding, the improvement of material segregation resistance and the fluidity under vibration in such fresh concrete in which differ the mixing method. In the future, the authors will plan to clarify the certainty of proposed model produced by this methods such as trying to visualize cement particle structure.

\section{Key words}

Concrete, Sand Enveloped with Cement, Mixing method, Bleeding, Particle structure model of cement in fresh concrete

\section{1. 緒言}

一般にコンクリートはセメント，水，骨材および混和 材料をほぼ同時にミキサに投入し，練り混ぜることによ り製造される．使用材料が同じでも練混ぜ方法，材料投 入順序を工夫することでフレッシュコンクリートや硬化 コンクリートの諸物性を改善できることは古くから知ら れていたが，その条件や効果に関する系統だった検討は 少ない ${ }^{1)}$. その後, 本研究で述べる SEC 工法 ${ }^{2)}$ や゙ブルミ キシング $(\mathrm{DM})$ 工法 $^{3)}$ など，練混ぜ水を分割して加えて 練り混ぜる分割混練法が提案された．SEC 工法で製造さ
れたコンクリート（以下, SECコンクリートと称す）は, 従来の一括で練り混ぜる方法（一括練混ぜ）に比べ，フ レッシュコンクリートの性質が変化し，また練混ぜ水を 最適の分割比率とすることで，ブリーディングの低減， 降伏值や粘着力の増加, 振動締固め性の向上, セメント の初期水和の向上などの大幅な改善効果を示すことが報 告されている ${ }^{2-5)}$. このSEC 工法は実用化され，吹付けコ ンクリートやプレキャストコンクリートの製造などに広 く適用されている ${ }^{6)-8)}$. また, SEC コンクリートは硬化後 の強度特性や耐久性の向上が図られることも報告されて

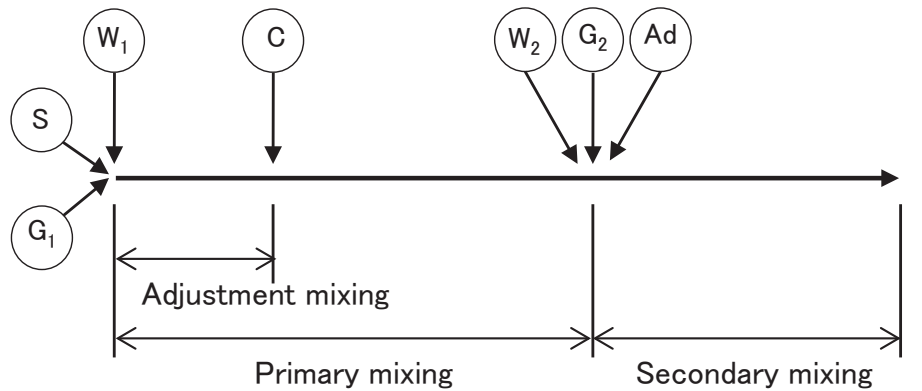

Fig.1 Mixing flow of SEC method.

\author{
S:Fine aggregate \\ C:Cement \\ G:Total corse aggregate \\ $\mathrm{G}_{1}$ :Corse aggregate(Decided by mixser) \\ $\mathrm{G}_{2}$ :Corse aggregate $(=\mathrm{G}-\mathrm{G} 1)$ \\ $\mathrm{W}_{1}$ :Primery water \\ $\mathrm{W}_{2}$ : Secondary water \\ Ad:Admixture(If necessary)
}

原稿受理 平成 31 年 2 月 28 日 Received Feb. 28, 2019 @2020 The Society of Materials Science, Japan

* リブコンエンジニアリング(株) †101-0044 東京都千代田区

Livecon Engineering Co., Ltd., Chiyoda-ku Tokyo 101-0044.

** 正 会員 東海大学 工学部土木工学科 干259-1292 平塚市北金目

Tokai University, Faculty of Engineering Department of Civil Eng., Kitakaname, Hiratsuka 259-1292. 
いる ${ }^{9), 10)}$.この品質向上のメカニズムに関しては, これま で様々な検討が行われてきた. 有力な説の一つは, セメ ントと水の練混ぜにおいて, セメントと一次水をキャピ ラリー状態 ${ }^{11)}$ となる量で練り混ぜた後 (一次練り), 残り の水 (二次水) を加え練混ぜて製造したセメントペース トでは, 従来の一括練混ぜに比べ, セメント粒子の分散・ 凝集構造が大幅に変化し, 水を保水しやすい構造となり ブリーディングを大幅に低減するとしている ${ }^{3), 12)}$. また, このブリーディング低減効果は，硬化コンクリートのペ 一ストと骨材界面に形成される脆弱層（遷移帯）を低減 または改質するために，SEC コンクリートが優れた硬化 後特性を発揮するとされている ${ }^{13)}$.

そこで本研究では, SEC コンクリートのブリーディン グ特性をより改善することを指向し，SEC 工法における 練混ぜ時間，練混ぜ水の分割比率，練混ぜ水の投入時期 および練上がり温度の影響等に関し実験的検討を行い, これらの練混ぜ条件の相違がブリーディングに及ぼす影 響について明らかにした。また，SEC コンクリートの改 質のメカニズムに関し，フレッシュコンクリート中のセ メント粒子の分散・凝集構造の変化から考察を加えた. なお，本論では SEC 工法によってブリーディングが低減 する現象を SEC 効果と称し，以下に用いる.

\section{SEC練混ぜ}

コンクリートの製造において練混ぜ水を分割して練り 混ぜる方法を，一般に分割練混ぜと称している。この分 割練混ぜ工法において，骨材に最適一次水量を加えて練 り混ぜて骨材表面水率を調整した（調整練混ぜ）後，セ メント（結合材）を加えて一次練混ぜを行い，その後二 次水を加えて練り混ぜる方法を SEC 練混ぜという ${ }^{2)}$. こ のような練混ぜを行うことで，コンクリート中のセメン トペーストを改質し，骨材表面に水セメント比の小さい セメントペースト層を形成させることを特長としている。 SEC 練混ぜのフローを Fig.1 に示す.この練混ぜにおける 一次練混ぜの役割は，(1)骨材に一次水を混ぜて表面に水 を一様に分布させる（調整練り）。(2)前述の骨材にセメン 卜（結合材）を加え，骨材周囲でセメントと一次水をキ ヤピラリー状態で効率的に練ることでペーストの改質を 行う。(3)骨材表面のキズやくぼみなどの欠陥の影響を少 なくし，ペーストと骨材との付着を向上させる。などで ある。一方、二次練混ぜの役割は，二次水を加えて練り 混ぜ, 要求された流動性と空気量を有する均質なコンク リートを得ることである。

なお，SEC 練混ぜにおける最適一次水量は使用材料と 配合によって変化するので, 事前に使用セメント(結合材) および細骨材での SEC一次水決定試験を行い, SEC 練混 ぜの最適一次水量基本式 ${ }^{14)}$ にて算出する.

\section{3. 試験概要}

\section{$3 \cdot 1$ 使用材料および配合}

コンクリートの使用材料は，セメントに普通ポルトラ ンドセメント（密度: $3.16 \mathrm{~g} / \mathrm{cm}^{3}$, 比表面積: $3190 \mathrm{~cm}^{2} / \mathrm{g}$ ), 細骨材に石灰岩砕砂（密度： $2.69 \mathrm{~g} / \mathrm{cm}^{3}$, 吸水率 : $1.66 \%$, 吸着水率: $1.59 \%$ ), 粗骨材に硬質砂岩砕石 (密度: $2.65 \mathrm{~g} / \mathrm{cm}^{3}$, 吸水率：0.71\%）を使用した. コンクリートの配合を Table 1 に示寸. なお，練混ぜ水の記号は W とし，一次と二次 水に分割する場合には, $\mathrm{W}_{1}$ および $\mathrm{W}_{2}$ とし, 全ての場合 に $\mathrm{W}=\mathrm{W}_{1}+\mathrm{W}_{2}$ である. また，表の $\mathrm{W}_{1}$ および $\mathrm{W}_{2}$ の值は， 先に示した最適一次水量基本式から算出したものである.

\section{$3 \cdot 2$ 試験方法}

セメントペーストおよびモルタルの練混ぜは容量 $10 l$ のホバート型ミキサを, コンクリートには容量 $60 l$ の二軸 強性練りミキサを用いた。練混ぜ方法は一括練混ぜ

(Normal-Mixing:NM）と分割練混ぜであり，セメントペ ーストの分割練混ぜは TSM（Two-Stage-Mixing），モルタ ルとコンクリートの分割練混ぜは SEC とした. Fig. 2 に練 混ぜ方法をまとめて示す．また，SEC 練混ぜにおける一

Table 1 Mix proportion of concrete.

\begin{tabular}{|c|c|c|c|c|c|c|c|}
\hline \multirow{2}{*}{$\begin{array}{c}\mathrm{G}_{\max } \\
(\mathrm{mm})\end{array}$} & \multirow{2}{*}{$\begin{array}{l}\mathrm{W} / \mathrm{C} \\
(\%)\end{array}$} & \multirow{2}{*}{$\begin{array}{c}\mathrm{s} / \mathrm{a} \\
(\%)\end{array}$} & \multicolumn{5}{|c|}{ 単位量 $\left(\mathrm{kg} / \mathrm{m}^{3}\right)$} \\
\hline & & & $\mathrm{W}_{1}$ & $\mathrm{~W}_{2}$ & $\mathrm{C}$ & $\mathrm{S}$ & $\mathrm{G}$ \\
\hline 20 & 55 & 40.7 & 103 & 97 & 364 & 729 & 1044 \\
\hline
\end{tabular}

The water content in the case of normal mixing is $200 \mathrm{~kg} / \mathrm{m}^{3}$.

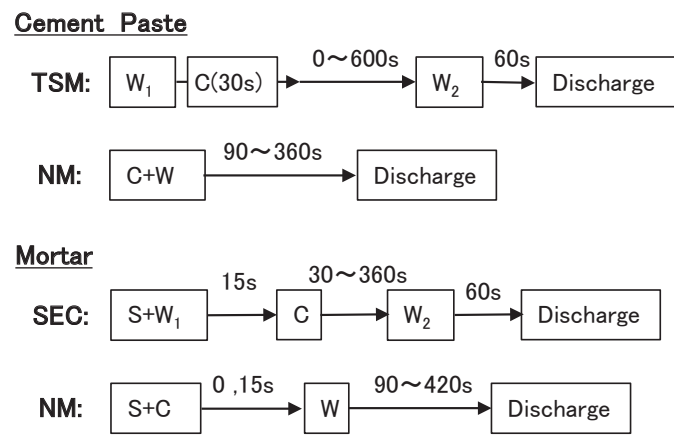

Concrete

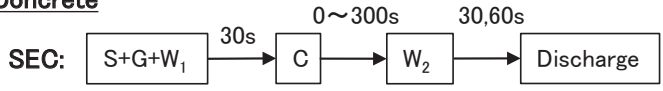

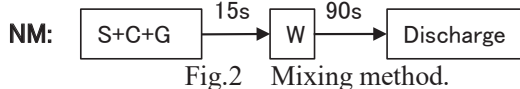

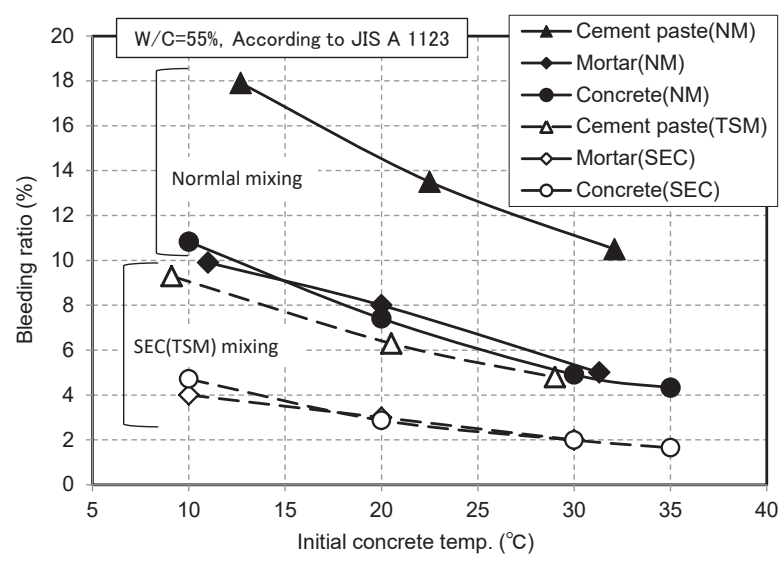

Fig.3 Relationship between initial temperature and bleeding ratio. 
次練混ぜ時間は 120 秒，二次練混ぜ時間は 60 秒を基準と するが，練混ぜ時間の影響に関する検討では，同図に示 す範囲で練混ぜ時間を変化させた.

ブリーディング試験はセメントペースト，モルタルお よびコンクリートとも JIS A 1123 に準拠して行った. なお, 本試験に用いた試験容器の寸法は，コンクリートの場合 $\phi 25 \times 28 \mathrm{~cm}$, セメントペーストとモルタルの場合 $\phi 10 \times$ $20 \mathrm{~cm}$ としたが，練混ぜ温度の影響を検討する試験では， 全ての場合に $\phi 25 \times 28 \mathrm{~cm}$ を用いた. また, 本研究ではコ ンクリート，モルタルおよびセメントペーストのブリー ディング試験結果を統一基準で評価するために，どの試 験方法（試験容器）の場合ともブリーディング率は, 試 料中の全水分量でブリーディング水量を除して求めた百 分率（ブリーディング率: BL 率) とした.

\section{4.試験結果および考察}

\section{$4 \cdot 1$ 練上り温度の影響}

コンクリートのブリーディングは種々な要因で変化す ることが知られている，ここでは，各練混ぜ方法ごと， 練上り温度によってコンクリート, モルタルおよびセメ ントペーストのブリーディングがどのように変化するか を検討した。コンクリート，モルタルおよびセメントペ 一ストの練混ぜは練上り温度を $10 \sim 35^{\circ} \mathrm{C}$ 範囲とし, 目 標温度が $10 ， 20 ， 30 ， 35^{\circ} \mathrm{C}$ とるように，材料および試 験容器などの温度を管理して行った。なお，モルタルお よびセメントペーストの配合は, Table 1 に示したコンク リートの配合の内，それぞれ粗骨材および細骨材と粗骨 材を除いたものとした。ブリーディング試験は，それぞ れの試験条件の練上り目標温度に管理された恒温室で行 った.また，各材料は練混ぜ 2 日前に練上り目標温度の 恒温室に保管して恒温とし，使用した。

Fig.3 に練上り温度とブリーディング率の関係を示す. 図より，コンクリート，モルタルおよびセメントペース トの場合とも，す心゙ての温度条件において分割練混ぜの 場合は，一括練混ぜの場合に比ベブリーディング率が 4 割程度に低下している。このことは，分割練混ぜによる ブリーディング低減効果は，練上がり温度が $10 \sim 35^{\circ} \mathrm{C}$ の 範囲であれば，常温（ $\left(20^{\circ} \mathrm{C}\right)$ の場合とほぼ同等な効果を 発揮することを示すものである。一方，す心゙ての条件で 練上り温度が低いほどブリーディング率は増加している.

また，コンクリートとモルタルのブリーディング率は, 練上がり温度が異なっていても同一温度において練混ぜ 方法ごとにほぼ等しい值を示しているが，セメントペー ストでは，コンクリートやモルタルの場合に比べ 2 倍程 度の值を示している。 このように，モルタルやコンクリ ートのブリーディング率がセメントペーストの場合より 大幅に小さい理由として，ブリーディング水が細・粗骨 材に捕捉されて上面まで上昇しないためであることが指 摘されている ${ }^{15)}$ ，骨材によるブリーディング水の捕捉効 果は骨材物性や配合, 試験容器などによって変化するこ とが知られているが，本試験条件の範囲では，この補足
効果は粗骨材よりも細骨材の方がより顕著であることが 推察される.

\section{$4 \cdot 2$ 練混ぜ時間の影響}

これまでにもコンクリートの練混ぜ時間とそのブリー ディングに関する検討は行われているものの，そのほと んどが一括練混ぜに関するものであって，コンクリート では練混ぜ時間が長いほどブリーディングが減少する傾 向であることが報告されている ${ }^{16)}$. 一方, 分割練混ぜに

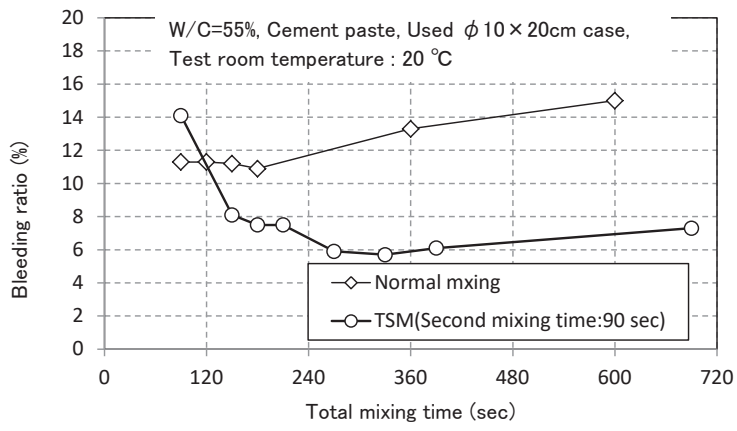

(a) Cement Paste

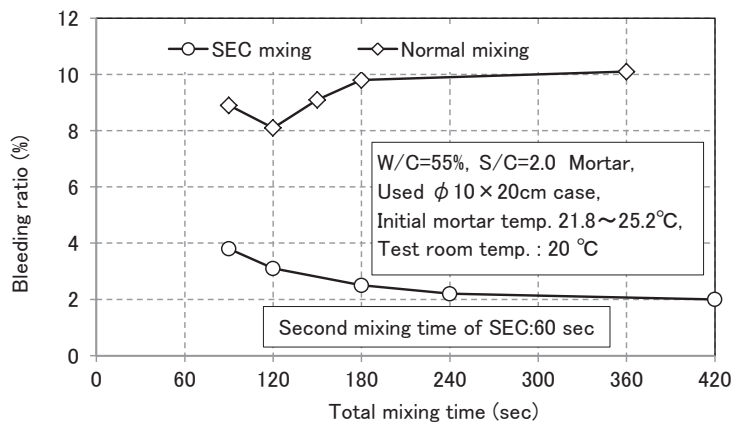

(b) Mortar

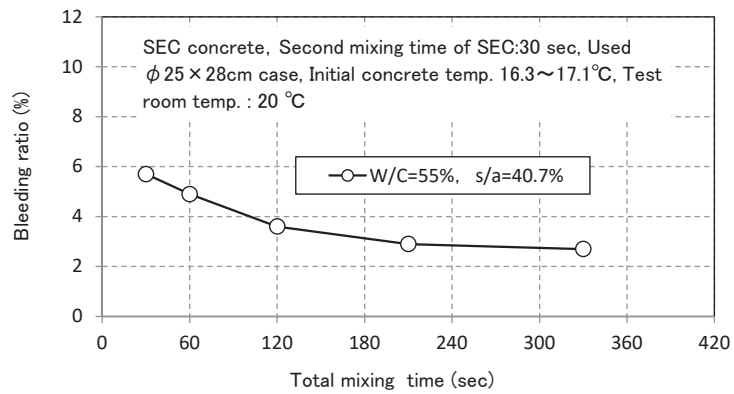

(c) Concrete

Fig.4 Relationship between mixing time and bleeding ratio.

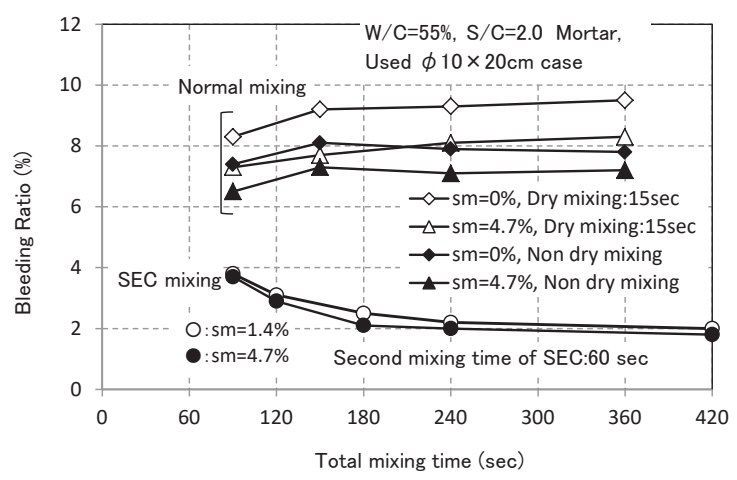

Fig.5 Influence of surface moisture of fine aggregate and mixing method on bleeding ratio of mortar. 
関しては，田澤らや城戸らがセメントペーストの場合に ついて報告している ${ }^{4), 17)}$ が，モルタルおよびコンクリー トについて検討した報告はない，そこでここでは，一括 および分割練混ぜ（SEC または TSM）における練混ぜ時 間がコンクリート，モルタルおよびセメントペーストの ブリーディング率に及ぼす影響について検討した。

Fig. 4(a)〜(c)は，順にセメントペースト，モルタルおよ びコンクリートの練混ぜ時閒とブリーディング率の関係 を示したものである. なお，分割練混ぜの場合，セメン トペースト，モルタルおよびコンクリートごとにそれぞ れ二次練混ぜ時間を 90 秒, 60 秒および 30 秒と一定とし， 一次練混ぜ時間を変化させてそれらの合計時間を練混ぜ 時間とした。

Fig.4(a)より，セメントペーストでは練混ぜ時間の増加 に伴い，一括練混ぜの場合ブリーディング率はほぼ一律 に増加するが，分割練混ぜでは一次練混ぜ時間の増加に 伴い，練混ぜ時間 330 秒（一次練混ぜ時間 240 秒）まで はブリーディング率が大幅に減少するが，それ以上長い 場合，ブリーディング率は僅かに増加する結果となった。 一次練混ぜ時間が長い場合にブリーディングが増加する 現象に関し，城戸らは一次練混ぜ時におけるセメントの 水和と練混ぜ水の蒸発により最適一次水セメント比と異 なる条件で一次練混ぜが行われていること，またセメン 卜の少量混合成分が影響していることを指摘している ${ }^{18)}$.

Fig.4(b)より，モルタルでは練混ぜ時間の増加に伴い， 一括練混ぜではブリーディング率は僅かに増加する傾向 を示すが，分割練混ぜ（SEC）では一次練混ぜ時間の増加 に伴いブリーディング率は小さくなり，一括練混ぜの $1 / 5$ 程度となった。また，Fig.4(c)の分割練混ぜ（SEC）のコ ンクリートでもモルタルの場合とほぼ同様な傾向を示し, 最適な一次水セメント比の条件で一次練混ぜ時間の増加 に伴い，ブリーディングを減少させる効果がより顕著と なる結果が得られた。

以上より，分割練混ぜにおける一次練混ぜ時間がブリ ーディング率に及ぼす影響は，骨材の有無によって異な り，モルタルおよびコンクリートでは，一次練混ぜ時間 が長いほど一律にブリーディングは小さくなった。

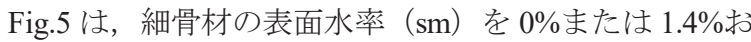
よび $4.7 \%$ とし、練混ぜ時間を変化させて一括および分割 練混ぜ（SEC）で製造したモルタルのブリーディング率を 示したものである。図より，分割練混ぜ（SEC）では細骨 材の表面水率の大小に関わらず，練混ぜ時間とブリーデ イング率の関係は Fig.4(b)の場合と同様に一次練混ぜ時間 の増加に伴い，ブリーディング率が小さくなる傾向を示 し，またブリーディング率の值は表面水率に関わらず各 練混ぜ時間でほぼ同等の值となっている。一方，一括練 混ぜでは細骨材の表面水率および空練り（Dry mixing）の 有無に関わらず，練混ぜ時間の増加に伴いブリーディン グ率は僅かに大きくなる傾向を示した。 また両表面水率 の場合とも空練りのない場合の方がブリーディング率は
小さく, さらに, 表面水率が大きい方がブリーディング 率は小さい值となっている.

以上の様にモルタル・コンクリートの配合が同一であ っても, 細骨材の有無や細骨材表面水の大小, および練 混ぜ方法の相違によって, ブリーディング率が変化する. この理由として, 練混ぜ中および練混ぜ後のセメント粒 子の凝集と分散状態, または再凝集の状態が様々な要因 で変化し, 練混ぜ水の分離を拘束する保水状態に差が生 じたためであることが指摘されている ${ }^{5), 12)}$. 次章では, 分割練混ぜ（SEC）工法によるブリーディング低減効果に 関し，セメント粒子の凝集・分散状態の観点から検討す る。

\section{SEC効果の発現に関する検討}

Fig.6 は粒子と液相の混合物において, 両容積比率の相 違による粒子間の液相の存在状態の一般的な分類を示し たものである ${ }^{11)}$. Fig.6(b)がフェニキュラー状態で水が粒 子の空隙で連結して網状組織を形成し，空気がその間に 点在している. 他方, Fig.6(d)はスラリー状態であり, 水 が粒子を完全に覆い自由水が存在するＳSEC コンクリー トの練混ぜにおいて, 一次練混ぜ時の状態は Fig.6(c)に示 すキャピラリー状態（粒子間の寸心゙ての空隙が水で満た

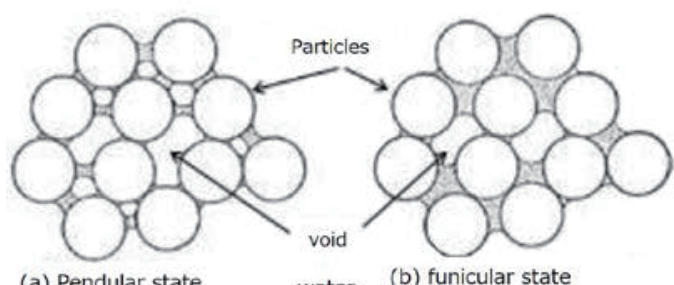

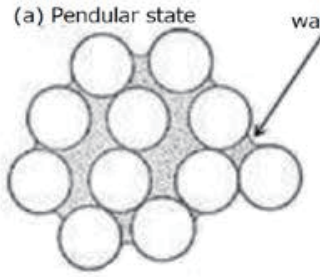

(c) Capillary state

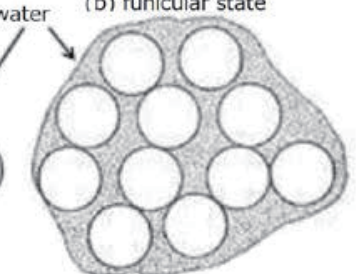

(d) Slurry state
Fig.6 Presence state of liquid phase between particles ${ }^{11)}$.

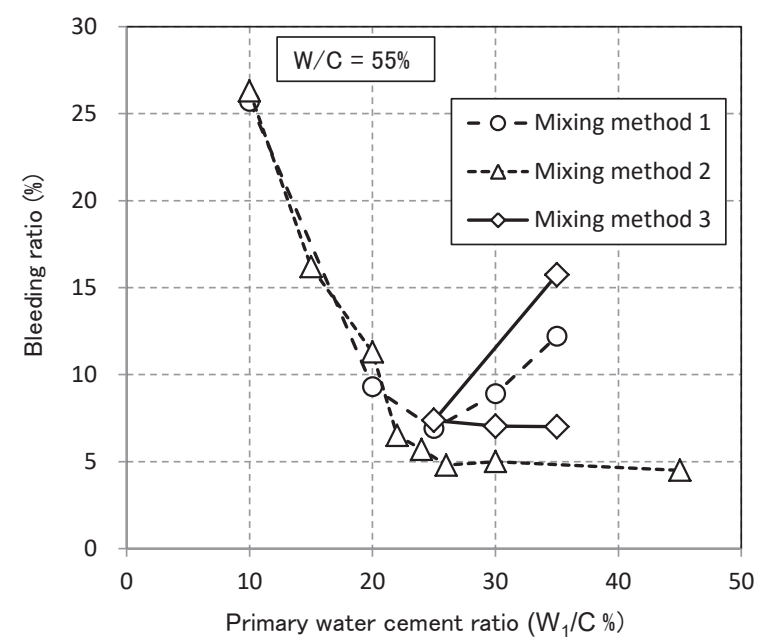

Fig.7 Bleeding ratio of cement paste at $\mathrm{W} / \mathrm{C}=55 \%$. 
され粒子表面にだけ気液界面が存在し自由水が無い状態 で，練混ぜエネルーも最大を示す.）とされている ${ }^{4)}$.ま た，セメントペーストでは W/C が 21〜25\%の場合キャピ ラリー状態，W/C がこれより小さい場合フェニキュラー 状態，大きい場合スラリー状態であるとされている.

Fig.7 は，次に示す(1)〜 (3)の方法で練混ぜて製造した $\mathrm{W} / \mathrm{C}=55 \%$ のセメント゚ースト(以下， CP で示す)のブリー ディング試験結果を示したものである．なお，CP の製造 方法がどの場合であっても，ブリーディング試験時の W/C はいずれも 55\%で一定である。(1)練混ぜ方法 1

(Mixing method 1) : $\mathrm{W}_{1} / \mathrm{C}=10 ， 20 ， 25 ， 30 ， 35 \%$ の条件 で一次練混ぜを行い，各々，最終 $\mathrm{W} / \mathrm{C}=55 \%$ となるように 二次水を加えて二次練混ぜを行い，CP を製造した場合で ある。(2)練混ぜ方法 2 (Mixing method 2)：練鉢内のセメ ントに水を連続的に添加して $\mathrm{W}_{1} / \mathrm{C}$ を徐々に増加させな がら一次練り混ぜを行う.この際, $\mathrm{W}_{1} / \mathrm{C}$ が 10, 15, 20, 22, 24, $26,30,45 \%$ となった時点で, 試料の定量を取り出し, 各々 $\mathrm{W}_{1} / \mathrm{C}$ の試料に $\mathrm{W} / \mathrm{C}=55 \%$ となるように二次水を加えて二 次練混ぜを行った場合である。(3)練混ぜ方法 3 （Mixing method 3): $\mathrm{W}_{1} / \mathrm{C}=35 \%$ の $\mathrm{CP}$ を練り， CP の一部を採取し て最終 $\mathrm{W} / \mathrm{C}=55 \%$ の $\mathrm{CP}$ を練混ぜてブリーディング試験を 実施した後. 残余の $\mathrm{CP}$ に $\mathrm{W} / \mathrm{C}=25 \%$ となるようにセメン 卜を追加して練混ぜ，この $\mathrm{CP}$ の一部を採取し $\mathrm{W} / \mathrm{C}=55 \%$ となるように水を添加して CP を練混ぜ試験を行う. 更に, 残余の $\mathrm{CP}$ に $\mathrm{W} / \mathrm{C}=30 \%$ となるように水を追加して練り， $\mathrm{CP}$ の一部を採取して最終 $\mathrm{W} / \mathrm{C}=55 \%$ の $\mathrm{CP}$ を練って試験を 実施する。これを繰返して $\mathrm{W} / \mathrm{C}=35 \%$ の $\mathrm{CP}$ を練り，最終 $\mathrm{W} / \mathrm{C}=55 \%$ の $\mathrm{CP}$ を練って試験を実施したものである.

図より，練混ぜ方法 1 では $\mathrm{W}_{1} / \mathrm{C}$ がキャピラリー状態 $\left(\mathrm{W}_{1} / \mathrm{C}=25 \%\right)$ で一次練混ぜを行った場合に，最小のブリー ディング率となっている．練混ぜ方法 2 ではフェニキュ ラー状態で一次練り混ぜした CP であっても水を追加し て，再度キャピラリー状態での練混ぜを行うことで，ブ リーディングが大幅に低減している，また，キャピラリ 一状態で一度練混ぜた後, $\mathrm{W}_{1} / \mathrm{C}$ が $26 \%$ より大きい条件で もブリーディングが低減している．練混ぜ方法 3 ではス ラリー状態の CP に, セメントを追加してキャピラリー状 態で一次練混ぜを行ったものであるが，この場合も練混 ぜ方法 1 および 2 の場合と同様にブリーディングが大幅 に小さくなっている.

Fig.8 は, Fig.7 の練混ぜ方法 2 および 3 の結果を模式的 に示したものである。図に示すようにキャピラリー状態 となる $\mathrm{W}_{1} / \mathrm{C}$ (図中の $\mathrm{W}_{01} / \mathrm{C}$ ) より 小さい $\mathrm{W}_{1} / \mathrm{C}$ から水を 加えた場合（図中の曲線(a)）または, 大きい $\mathrm{W}_{1} / \mathrm{C}$ からセ メントを加えた場合（図中の曲線(b)）であっても，練混 ぜ過程のいずれかの段階でキャピラリー状態 $\mathrm{W}_{01} / \mathrm{C}$ で練 混ぜた CP は，通常の一括練混ぜで製造した CP よりブリ 一ディングが大幅に低減することが判明した。すなわち, 分割混練法によりブリーディングを低減させるためには, キャピラリー状態で一次練混ぜを行うことが肝要である と推察される.
以上のセメントペーストにおける分割練混ぜの効果発: 現のメカニズムの知見を基に，以下に SEC コンクリート の場合について検討する.

通常，コンクリートの練混ぜ試験は JIS A 1138 「試験室 におけるコンクリートの作り方」によって, 試験室で実 施されている. Fig.9 に試験ミキサによるコンクリートの 練混ぜの際の加水時における, セメントおよび細・粗骨 材と水との遭遇状態を示す. Fig.9(a)の一括練混ぜの場合 には骨材は「表面乾燥飽水状態またはこれに近い湿潤状 態」であり，JIS により練混ぜ手順には特に規程はないも のの骨材とセメントをミキサに投入した後，一定時間の

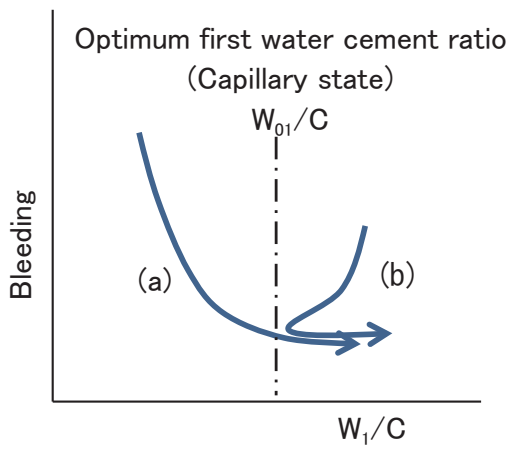

Fig. 8 Concept of bleeding of CP via capillary state.

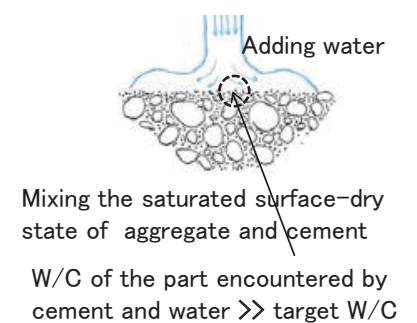

(a) Normal mixing

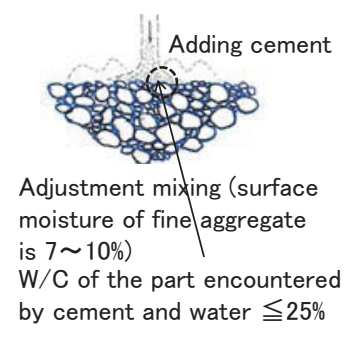

(b) SEC mixing
Fig.9 Encounter state of cement and water in test mixer.

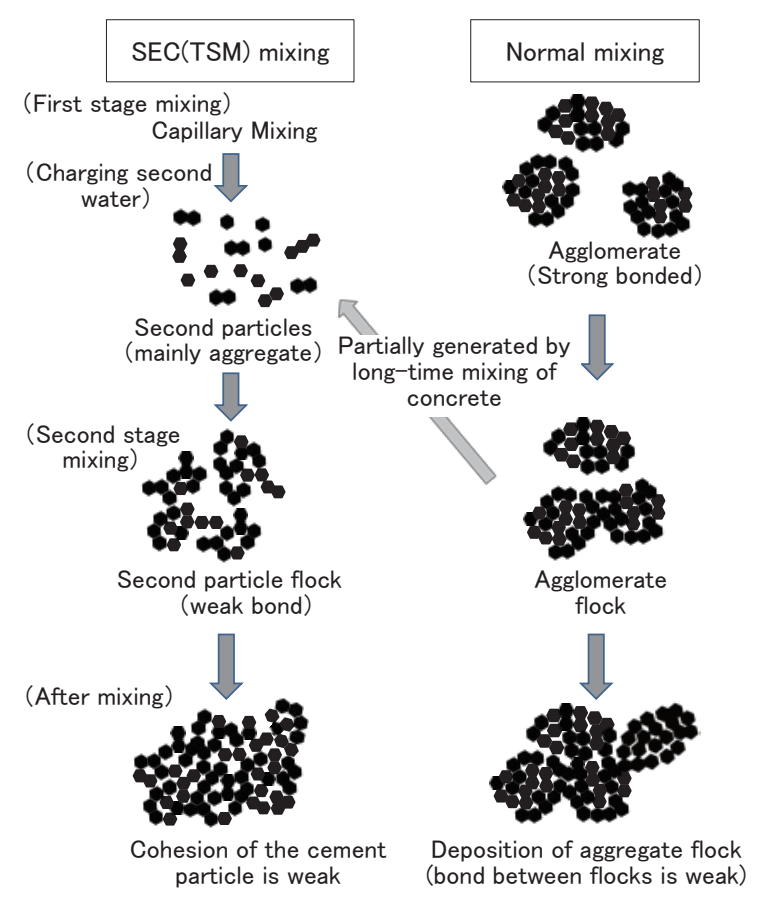

Fig.10 Concept of cement particle bonding state in concrete. 
空練りを行った後, 水を投入して練混ぜる場合が多い. この空練り後, ミキサ内では細・粗骨材間にセメントが 均等に分散した状態となっており，その上部から練混ぜ 水の全量が投入される。この場合のセメントペーストに 着目すると, その水セメント比 (W/C) は最終 (計画配合) の值より，大きな值から徐々に最終の值へと小さくなっ て行くことになる. 従って, コンクリートを一括練混ぜ する場合その練混ぜの過程で，セメントペーストは常に スラリー状態となっている.

一方, Fig.9(b)の SEC コンクリートの練混ぜを行う場合 には, 数\%程度の表面水率に調整した細骨材と表乾状態の 粗骨材を用い，一次水 $\left(\mathrm{W}_{1}\right)$ を投入して調整練混ぜを行 った後セメントを投入して一次練混ぜを行ない，その後 二次水 $\left(\mathrm{W}_{2}\right)$ を投入して二次練混ぜを行う。この場合, セメントペーストは最終の W/C より小さいW/Cから徐々 に最終の W/C へと大きくなって行くことになる.従って， SEC コンクリートの練混ぜの場合には，そのセメントペ ーストは練混ぜ直後にフェニキュラー状態であり, 次に キャピラリー状態での練混ぜを経て， スラリー状態のコ ンクリートとなる.

以上のことから，コンクリートの練混ぜの過程で，セ メントペーストがキャピラリー状態となる時期の有無が コンクリートのブリーディング特性に影響するものと推 察され，一括と SEC コンクリートとのフレッシュ性状の 相違をもたらすものと考えている.

\section{6. フレッシュコンクリートのセメント粒子構造}

練混ぜ方法が相違するコンクリートにおけるセメント 粒子の構造については, 例えば文献 12)などの研究が行わ れている、筆者らは，これらの研究を参考に SEC コンク リート中のセメント粒子構造を Fig.10のように推察した.

SEC 練混ぜの場合は，一次練混ぜにおいて高い剪断力 で練混ぜられたセメントは，凝集することなく分散され る(図中の Capillary Mixing)。田澤ら ${ }^{18)}$ は，セメントペー ストのダブルミキシング効果に関する検討から， 二次練 混ぜ中またはその直後にセメント粒子の凝集力が最大と なる時期が存在することを指摘しているが，この凝集力 により二次練混ぜ後にセメント粒子は，二次粒子フロッ ク（Second particle frock）から成る弱い立体的結合を形成 し，練混ぜ水を緩く拘束する。この場合のセメント粒子 結合は内部に拘束水を有するので，一括練混ぜの場合と 比ベてブリーディングが減少する.

一方，一括練混ぜの場合は，練混ぜ開始時では，セメ ントと過剰な水を練り混ぜると，急速にセメント粒子の 凝集体（アグロメレート：粒子数 30 個程度）が生成され る.この粒子の結合は van der Waals 力（引力）が主とな る強い結合と考えられる，セメント粒子表面には負の電 位を持つとしても，水中ではクーロン力は遮へいされる ので斥力は小さい. また, 電気二重層は発達しておらず これによる乕力も小さい. 更に, 練混ぜ終了時には凝集 体同士が弱い結合をしたり（アグロメレートフロック）,
堆積したりする.このような粒子構造が，ブリーディン グ量が多くなり, 流動性が悪くなることの原因となる. また, 一括練混ぜの場合であっても, 長時間の練混ぜに より粗骨材の衝撃効果でアグロメレートが壊され, 部分 的に二次粒子となって SEC 練混ぜの効果を発揮すること もある (図中斜め左上への矢印)。このように，練混ぜ方 法によってセメント粒子の結合状態が異なるので，ブリ ーディング特性が異なったものと考えられる.

\section{7. 結言}

SEC コンクリートのブリーディング特性をより改善す る目的で, 練混ぜ方法や材料投入手順, 材料温度の相違 などがブリーディングに及ぼす影響について実験的に検 討するとともに, SEC 効果の発現メカニズムに関し検討 した結果, 以下の結論が得られた. なお, 本研究で使用 した細・粗骨材は，それぞれ一種類のみであるが，今後， SEC 効果に及ぼす骨材の種類や岩種等の影響についての 検討が必要である。

(1) 分割練混ぜによるブリーディングは, コンクリート, モルタルおよびセメントペーストの場合とも，一括練混 ぜの場合に比べブリーディング率が 4 割程度に低減し, またその低減効果は, 練上がり温度が $10 \sim 35^{\circ} \mathrm{C}$ 範囲で, 常温の場合とほぼ同等な効果を発揮する.

(2) 分割練混ぜにおける一次練混ぜ時間がブリーディン グ率に及ぼす影響は，骨材の有無によって異なり，モル タルおよびコンクリートでは，一次練混ぜ時間が長いほ ど一律にブリーディングは小さくなった。一方, セメン トペーストでは, 一次練混ぜ時間の増加に伴い, 練混ぜ 時間 330 秒（一次練混ぜ時間 240 秒）まではブリーディ ング率が大幅に減少するが，それ以上長い場合，ブリー ディング率は僅かに増加する結果となった.

(3) セメントペーストの練混ぜにおいて, 練混ぜ過程のい ずれかの段階でキャピラリー状態で練混ぜを行うと, そ のブリーディングは大幅に低減することが判明した.

(4) (3)の結果から SEC 効果の発現は, コンクリートの練混 ぜの過程で，コンクリート中のセメントペーストがキャ ピラリー状態となる時期の有無に依存するものと推察し た.

(5) SEC 効果の発現メカニズムに関し, コンクリート中の セメント粒子の凝集・分散構造の相違を用いて, SEC コ ンクリートのブリーディング低減モデルを提案した。

今後は, これらセメント粒子構造の可視化を試みるな どの方法で, 提案モデルの妥当性を明確にしたいと考え ている.

\section{参 考 文 献}

1) T. Yoshida, "On the order in which the concrete material should be charged into the mixture", Kyushu University, Faculty of Engineering Reports pp.3-6(1931).

2) (General Foundation corporation) Public works research center, "SEC concrete which made by tow stage mixing 
for improvement of performance ", Construction technical examination certificate report, No.0309, pp.30-38 (2003).

3) E. Tazawa, Y. Matsuoka, S. Kaneko and Y. Ito, "On the properties of fresh cement paste prepared by double mixing" , The Proceeding of JCI, Vol.4, pp.125-128(1982)

4) E. Tazawa and T. Kasai," Double mixing effects of fresh cement paste", Journals of JSCE, No. 396, Vol.9, pp. $135-142(1988)$.

5) Y. Nakagawa, S. Fujii, K. Yoshioka and E. Tazawa, "Effect of double mixing on early hydration of cement", the Proceeding of JCI, Vol.29, No.1, pp 51-56(2007).

6) Y. Ito, T. Tosaka, S. Sakurai, M. Suenaga and T. Asakura, "Study on construction performance of high quality shotcrete", Journals of JSCE E, No. 4, Vol.65, pp. 419-430(1988).

7) T. Kasai, E. Tazawa and H. Isogai, "Application of double mixing method for steam cured precast concrete", the Proceeding of JCI, Vol.31 , No.1 , pp.2185-2190(2009)

8) S. Suzuki, E. Tazawa, J. Paweena and T. Kasai, "Study on frost damage characteristics and pore structure of pre-cast concrete manufactured by double mixing metod", the Proceeding of JCI, Vol.36, No.2, pp. 355-360(2014).

9) H. Kaga, Y. Yamamoto, K. Kuroha, M. Hayakawa and Y. Ito ," Study on S.E.C. concrete (Characteristics and Strength)", Summaries of technical papers of annual meeting architectural institute of japan, pp.57-58(1980).

10) K. Kishitani, Y. Ito, H. Kaga and Y. Yamamoto, "SEC concrete method - Basic theory and characteristics, practical application”, Building technology, No.380, pp.1-18(1983).

11) S. Miwa, "Commitment to powder engineering", Nikkan Kogyo Shimbun, pp.43(1981).

12) K. Yoshioka, "Influence of mineral composition and mixing method on the bonding structure of cement particles", Doctoral dissertation, pp.56-67(1999).

13) R. Shionaga, K. Toda, Y. Ito and H. Takahashi, "The evaluation of the hydration rate and the width of the interfacial transition zone and the influence for the water permeability of the concrete mixed by separated mixing method", the Proceeding of JCI, Vol.37, No.1, pp.541-546(2015).

14) (General Foundation corporation) Public works research center, "SEC concrete which made by tow stage mixing for improvement of performance ", Construction technical examination certificate report, No.0309, pp.68-72 (2003).

15) S. Date, K. Hasegawa, M. Ikeda and Y. Tsuji, "Influence of sand property on bleeding behaviors of mortar produced by sand enveloped with cement method", the Proceeding of JCI, Vol.26, No.1, pp.615-620(2004).

16) K. Kishi, T. Watanabe, K. Yamada and T. Uomoto, "Effect of type of mixser and mixing time on properties of concrete", Journals of JSCE, No.402, V-10, pp.53-60(1989).

17) R. Shiroto, T. Yamamoto, Y. Ito and T. Kasai, "Influence of primal mixing time by separate mixing on the properties of flesh concrete", the Proceeding of JCI, Vol.40, No.1, pp.1065-1070(2018).

18) E. Tazawa and T. Kasai, "Mechanism and effects of double mixing on properties of cement paste", Journals of the Society of Materials Science, Japan, Vol.39, No.442, pp.1007-181(1990). 